\title{
THE WORLDWIDE CHANGE IN THE BEHAVIOR OF INTEREST RATES AND PRICES IN 1914
}

\author{
Robert B. BARSKY* \\ University of Michigan, Ann Arbor, MI 48109, USA \\ N. Gregory MANKIW* \\ Harvard University, Cambridge, MA 02138, USA \\ Jeffrey A. MIRON* \\ University of Michigan, Ann Arbor, MI 48109, USA \\ David N. WEILL* \\ Harvard University, Cambridge, MA 02138, USA
}

\begin{abstract}
This paper evaluates the role of the destruction of the gold standard and the founding of the Federal Reserve, both of which occurred in 1914, in contributing to observed changes in the behavior of interest rates and prices after 1914. The paper presents a model of policy coordination in which the introduction of the Fed stabilizes interest rates, even it the gold standard remains intact, and it offers empirical evidence that the dismantling of the gold standard did not play a crucial role in precipitating the changes in interest rate behavior.
\end{abstract}

\section{Introduction}

Comparisons of the behavior of macroeconomic time series before and after a major regime change provide particularly valuable evidence on the effects of alternative monetary policies. The year 1914 provides a dramatic example of such a change in regime.

From one point of view, the monetary regime is defined by the stochastic process jointly generating money, prices, and nominal interest rates (and perhaps other macroeconomic variables as well). Shiller (1980), Mankiw and Miron (1986), Miron (1986), Mankiw, Miron and Weil (1987), and others ${ }^{1}$ document that the stochastic behavior of United States nominal interest rates

\footnotetext{
*We thank Robert Barro, Giorgio Basevi, John Campbell, Robert Gordon, Anna Schwartz, and Alan Stockman for helpful comments and Carey Treado for research assistance.

${ }^{1}$ See also Glass (1927), Macauley (1938), Friedman and Schwartz (1963), Canova (1986) and Barro (1987).
} 
changed sharply in $1914 .^{2}$ Seasonals and other forms of predictable transitory variation in short term nominal rates, which had previously been a prominent feature of the data, almost completely disappeared, leaving short rates nearly a random walk. Clark (1986) finds that the disappearance of seasonality was not confined to the United States but rather occurred worldwide. $^{3}$ Shiller and Siegel (1977) and Barsky (1987) suggest that the stochastic behavior of inflation underwent a significant metamorphosis at about the same time. While inflation in both the United States and Britain was approximately white noise from the earliest available data through 1913, the inflation processes show moderate but non-negligible persistence after 1914.

From an institutional point of view, the change in monetary regime in 1914 was equally notable. The outbreak of war in Europe in August, 1914 was accompanied by the suspension of specie payments in many countries a shock from which the international gold standard never fully recovered. In November, the Federal Reserve began operations, fulfilling the charter set out for it by legislation from the previous December. Though England, Germany, and France had long histories of central banking, the United States had not had a central bank since 1836 .

The topic of this paper is the relationship between the changes in monetary institutions surrounding 1914 and the discontinuity in the stochastic behavior of interest rates and prices. More specifically, we ask a key question that bears on the role of the economic policy regime in determining the behavior of macroeconomic and financial variables: which of the institutional shocks bears the primary responsibility for the observed changes in the statistical relationships? Friedman and Schwartz (1963), Shiller (1980), Mankiw and Miron (1986), Miron (1986), and Mankiw, Miron, and Weil (1987), all focusing on the United States, attribute the 'smoothing' of interest rates to the founding of the Federal Reserve, which, after all, was established in considerable part with this end in mind. Clark (1986), however, challenges this view with an argument that appears compelling prima facie. He notes that the disappearance of seasonal fluctuations in nominal interest rates was a worldwide phenomenon. Although the United States was by 1914 certainly not a small country, neither was it so dominant that it should have been able, acting on its own, to alter greatly the stochastic processes of world prices and interest rates. Instead, Clark suggests, it would appear more plausible to attribute the altered behavior of nominal interest rates to the dissolution of the worldwide gold standard at the start of World War I. A serious examination of these competing hypotheses is the goal of this paper.

\footnotetext{
${ }^{2}$ Mankiw, Miron and Weil (1987), using a switching regression technique, narrow the likely date of the change in the stochastic process of the nominal rate to the interval between December 1914 and March 1915. They also show that the behavior of the term structure at the short end of the yield curve changed more or less concurrently in a way consistent with the qualitative predictions of the expectations theory of the term structure.

${ }^{3}$ Morgenstern (1959) makes the same point.
} 
The paper is organized as follows. In section 2 we provide some historical background, placing the institutional developments - the founding of the Fed, possible interactions between the various central banks, war, suspensions and resumptions of specie payments - in perspective. In section 3 we characterize the stochastic behavior of nominal interest rates and inflation rates before and after 1914 for the United States and Britain. We obtain a sharp characterization of the change in the nominal rate processes: an almost complete disappearance of forecastable variation, including seasonality, in nominal rates for both countries. We also find some indication of change in the inflation process: the emergence of positive serial correlation where inflation had previously been closer to white noise.

Section 4 of the paper considers the a priori plausibility of the hypothesis that the founding of the Fed was an important factor in stabilizing interest rates after 1914, given the relatively modest size of the United States in international trade and finance. We propose that policy interaction in a many country game might provide the missing link. We present an example in which interest rate stabilization, though desired by each central bank, occurs only if all countries have central banks. In our example this follows because countries pursuing interest rate stabilization alone experience undesirable gold flows. The model suggests that the founding of the Fed might have been important because it marked the beginning of a new era in which all major countries had a central bank.

Section 5 presents a number of pieces of evidence bearing on role of the Fed versus the role of the gold standard in contributing to the changes in the stochastic behavior of interest rates and prices. ${ }^{4}$ We first examine the switch from fixed to flexible rates at the collapse of the Bretton Woods system. We find that it was not accompanied by the same kinds of changes in interest rate behavior that occurred in 1914, which casts doubt on the destruction of the gold standard as the principal cause of the change in the stochastic processes for interest rates in 1914. Our second piece of evidence comes from examining the correlations across countries of both interest rates and price levels. We find that the changes in these correlations after 1914 were modest at best, and they do not appear to move in the direction implied by a simple shift from fixed to flexible rates. This evidence therefore also suggests that the introduction of the Fed was an important factor in the 1914 change in regime.

In section 6 we present a rather qualified evaluation of the likelihood that the stabilization of the nominal interest process was unaccompanied by an alteration of the real rate process, an assumption of the theory of interest rate targeting in Barro (1987). In particular, we examine whether the smoothing of the seasonal in nominal rates in the second regime reflected a smoothing of the seasonal in real rates. We wish to evaluate Shiller's (1980)

\footnotetext{
${ }^{4}$ We also discuss briefly the hypothesis that World War I per se was responsible for the change in regime.
} 
suggestion that the seasonality that was removed from the nominal rate may have reappeared in prices and thus was not purged from the real rate. We use a different interest rates series, different statistical techniques, as well as data for an additional country to address this question. Unfortunately, the data exhibit less power to judge this issue than we had hoped. The volatility of inflation during both subperiods leads to the finding of very large standard errors for the estimated seasonal pattern in real rates, so we confirm Shiller's conclusion that 'we can't say with any confidence whether a policy of eliminating the seasonal pattern in nominal rates reduced the seasonal pattern in real rates'.

Section 7 concludes the paper.

\section{Historical overview}

The period from 1879 to 1914 stands out in the history of world monetary systems as the time when the world came closest to operating on textbook version of the gold standard. The period is also unusual, although not unique, in that the United States was the only major economic power that did not possess a central bank. The period after 1914 differed drastically from the period before 1914 in several respects. As a result of World War I, the international gold standard was suspended in most countries, and it returned for only limited time and in much weakened form. The Federal Reserve System began operations in 1914, providing the United States with centralized monetary control for the first time in almost eighty years. ${ }^{5}$ We analyze in sections 4 and 5 the likelihood that one or both of these institutional changes caused the changes in financial markets that occurred at the same time. In this section we review the major historical events connected with the changes in institutions.

\subsection{Central banking before 1914}

By the last quarter of the nineteenth century, most of the important economic powers other than the United States had established central banks. These banks included the Bank of England, established in 1694, the Bank of France (1800), the State Bank of Russia (1860), the German Reichsbank (1876), and the Bank of Japan (1882). ${ }^{6}$ Some of these banks were closer to ordinary (state sanctioned) commercial banks than to modern central banks, and none of them engaged in what would today be considered a complete set of central banking activities. The Bank of England was the most developed of these central banks in terms of exercising central banking functions, and it

\footnotetext{
${ }^{5} A$ variety of institutions, including the United States Treasury and the New York Clearing House, had performed limited central banking functions at times during the National Banking Period. On the role of the Treasury, see Andrew (1907) and Timberlake $(1963,1978)$. On the New York Clearing House, see Timberlake (1984).

${ }^{6}$ Bloomfield (1959) counts central banks or quasi-central banks in an additional sixteen countries as of 1880 , as well as three more by 1907 .
} 
was widely regarded as playing a central role in enforcing the international gold standard. ${ }^{7}$

It was universally recognized during this period that the crucial objective of central banks was to maintain a supply of gold reserves sufficient to insure convertibility [Bloomfield (1959, p. 23)]. Central banks accomplished this task through a number of different means, the most important of which was the manipulation of the interest rate at which they would discount private debt. Other methods for safeguarding the gold reserve included open market operations and changes in the regulations regarding convertibility. The Bank of England relied heavily on changes in the discount rate (Bank Rate), while the continental central banks made more frequent use of other methods [Eichengreen (1985, p. 13)].

Contemporary discussions about how the Bank of England should set Bank Rate indicate the objectives that pre-1914 central banks pursued when they were not handcuffed by the need to insure convertibility. Sayers (1936) states that the Bank gave weight to the condition of the domestic economy; specifically, the Bank anticipated the effects of future events on interest rates and attempted to set Bank Rate at the level it expected to maintain. The First Interim Report of the Cunliffe Committee (1918) suggested that Bank Rate be raised in response to permanent but not temporary disturbances in the money market. Jevons (1884) argued that the Bank should not raise the Bank Rate in response to the regular autumnal drains on the Bank's reserves since these replenished themselves in the normal course of business. Bagehot claims in Lombard Street (1873) that the Bank had an 'inescapable duty' to act as lender of last resort. Whatever the objectives of the world's central banks, they were either very skillful or very lucky in maintaining convertibility since the period was marked by few exchange crises [Bloomfield (1959, p. 9)].

The United States stood out from the other economic powers of this period in lacking a central bank until the founding of the Federal Reserve System in November of 1914. The events precipitating the founding of the Fed started with the Panic of 1907, which led to the passage of the AldrichVreeland Act, a temporary measure designed to allow New York City Banks some leeway in dealing with emergencies, and to the creation of the National Monetary Commission, a congressional and academic committee that undertook to study all aspects of the domestic and international banking system. The Commission's Report, published in 1910, laid the basic blueprint for the Federal Reserve Act, which became law in December of 1913. The heads of the twelve banks met in August of 1914 to discuss the details of the system's organization, and the banks opened for business in November of that year.

The Fed was created mainly to eliminate dramatic interest rate fluctuations through provision of an 'elastic currency' [Laughlin (1912), Willis

\footnotetext{
${ }^{7}$ See Bordo and Schwartz (1984), Eichengreen (1985), and the references therein for discussion of this point.
} 
(1915), Glass (1927), Warburg (1930)]. There were, of course, other central banking activities that the Fed was expected to perform, particularly the elimination of interregional interest rate differentials and the associated pyramiding of reserves [Gendreau $(1979,1983)$, White (1983)]. The Fed's crucial objective, however, was the accommodation of the regular seasonal fluctuations in money markets as well as the sterilization of more erratic interest rate fluctuations associated with financial panics. It is useful to note that the Fed was conceived and created before the outbreak of World War I and the suspension of the gold standard. The founders of the Fed had no way of knowing that the Fed would find itself, almost precisely at the moment of its birth, in a new kind of international monetary situation. Instead, they expected that the Fed would operate under gold standard regime that had come to be the accepted system of international monetary arrangements [Friedman and Schwartz (1963, p. 191)].

\subsection{The gold standard and World War I}

The exact definition of the gold standard varies considerably among different authors, and the features of such a standard that are important depend on the question at hand. Our discussion here focusses on those features of a gold standard that are crucial to determining the conditions under which interest rates and prices are determined both within and across countries.

Eichengreen (1985) ascribes three basic characteristics to a classical gold standard: (1) convertibility between domestic money and gold at a fixed official price; (2) freedom for private citizens to export and import gold; and (3) a set of rules relating the quantity of money in circulation to that country's gold stock. ${ }^{8}$ The first two features imply that a gold standard establishes a system of fixed exchange rates between national currencies. This places strong restrictions on the feasible monetary and fiscal policies available to any open economy operating under a gold standard [Sargent (1986, pp. 45-46)].

Three different types of rules relating the quantity of fiat money to gold reserves were commmon [Bloomfield $(1959$, p. 18)]. Fiduciary systems required all notes above a certain limit to be backed 100 per cent by legal reserves. Proportional systems required notes to be covered by a minimum proportion of legal reserves. Combination systems involved aspects of both systems. If a central bank (in a closed economy) operated under a fiduciary system and was not at the constraint, then it could affect rates and the price level by altering the mix of notes relative to gold.

As mentioned above, the thirty-five year period preceding 1914 constituted the world's most direct experience with a classical gold standard. All the major economic powers in Europe and Asia, as well as the United States and

\footnotetext{
${ }^{8}$ See also the papers in Bordo and Schwartz (1984) for detailed discussions of the features of a gold standard.
} 
most Latin American countries, maintained convertibility during this period. There were only a few devaluations by countries operating on the gold standard, and only a small number of economic powers participated in any other kind of monetary arrangement. ${ }^{9}$ The period is also noteworthy for the comparative absence of balance of payments crises or other traumatic events associated with the exchange rate regime.

The suspension of the gold standard in 1914 was the direct result of the outbreak of World War I in August, 1914. Within a few months of the outbreak of war (indeed in some cases even before the formal declaration), most countries had suspended gold payments either de jure or de facto [Brown (1940, pp. 7-26)]. When the war ended, most countries had experienced such rapid inflation during the previous four years that an immediate return to convertibility at anything like the prewar parities was unthinkable. It was the announced aim of virtually all countries, however, to return to the gold standard quickly, and a great deal of macroeconomic history of the subsequent period can only be understood in this light. ${ }^{10}$

The correct characterization of the system of international monetary arrangements varies considerably over the 1914-1933 period. During the War the major currencies floated relative to one another, but there was sufficient controls on prices, gold movements, and international capital flows that any attempt to describe the system in simple terms is bound to be inaccurate. The period from 1919-1925 appears to be a relatively clean case of floating rates. From 1926-31, several countries resumed convertibility, so that the world moved back toward a gold standard. It appears to be the consensus, however, that the operation of the gold standard during this period did not approximate its smooth opertion before 1914. Beginning with Britain's devaluation of sterling in the fall of 1931, a number of countries left the gold standard, this time for good. The final blow to the international gold standard was the departure of the United States in 1933 [Eichengreen (1985, pp. 19-24)].

\section{Evidence of the changes in the behavior of interest rates and prices}

In this section we document the changes in the behavior of nominal interest rates and inflation rates that occurred after 1914. We present results for two countries, the United States and Britain. These two countries, at least as of the second period, were the world's major economic powers, and New York and London were its key financial centers. In addition, there are consistent data series for these two countries. To the extent that there are

\footnotetext{
${ }^{9}$ China, El Salvador, and Honduras maintained silver standards during this period [Eichengreen $(1985$, p. 6)].

${ }^{10}$ See, for example the First Interim Report of the Cunliffe Committee (1918) in Britain. Keynes (1923) was an outspoken opponent of the return to gold.
} 
data for other countries, they confirm the main results presented below. 1 We examine the behavior of financial markets in both countries for two periods (1890-1910 and 1920-1933) that do not overlap the founding of the Fed or World War I. ${ }^{12}$ The objective is to document the change in regime in a way that avoids problems of how the transition took place.

All our data series are monthly. The nominal interest rate series for the United States consists of observations from the first week of each month on the three month time loan rate available at New York City banks. ${ }^{13}$ The nominal rate series for Britain consists of observations from the first week of the month on the three month rate on bankers' bills available in London, as reported in the Economist. ${ }^{14}$ The price series for the United States is the Wholesale Price Index for all commodities published by the Bureau of Labor Statistics. The numbers are averages of observations collected throughout the month. The price series for Britain is an index of the wholesale prices of 45 commodities, developed by Augustus Saurbeck and continued after his death by the Statist. ${ }^{15}$ It is (purportedly) measured during the last week of each month. We have shifted this series forward one month in all of the calculations reported below, so it is only one week out of alignment with our interest rate series.

Table 1 shows the autocorrelation function for the nominal interest rate in the United States and Britain for the two different sample periods. In both countries the short rate was mean reverting during the $1890-1910$ period. The autocorrelations of the level of rates damp quickly, and the first differences show significant negative autocorrelation. In the 1920-1933 period, the autocorrelations die out less quickly, and there is less evidence of autocorrelation in the first differences. In the first sample the autocorrelations indicate that the short rate is more persistent in Britain than it is in the United States. In the second sample, the autocorrelation functions are almost identical.

In table 2 we show regressions of the short rate on its own lagged values, including and excluding seasonal dummies. These results confirm those in table 1. In the early period, the coefficient on the lagged short rate is significantly less than one in both countries, and there is quantitatively important evidence of seasonality. In the later period, the coefficient on the lagged short rate is not significantly different from one and there is much less

\footnotetext{
${ }^{12}$ Our results are essentially unchanged if we omit the years 1929-1933 from the second sample period.

${ }^{13}$ The series is described more fully in Mankiw, Miron and Weil (1987).

${ }^{14} \mathrm{This}$ is the open market rate on bankers' bills, not the Bank of England's discount rate, known as Bank Rate.

${ }^{15}$ See the Economic Journal, 1886, p. 592 ind p. 648 for details on the construction of the index.

"See especially Clark (1986) and Morgenstern (1959). Clark shows that interest rate seasonality diminished substantially after 1914 in France and Germany, as well as in the United States and Britain. Morgenstern notes that the seasonality of financial variables diminished significantly in all four countries.
} 
Table 1

Autocorrelations of the short rate."

\begin{tabular}{|c|c|c|c|c|c|c|c|c|}
\hline & \multicolumn{4}{|c|}{ United States } & \multicolumn{4}{|c|}{ Britain } \\
\hline & \multicolumn{2}{|c|}{$1890-1910$} & \multicolumn{2}{|c|}{$1920-1933$} & \multicolumn{2}{|c|}{$1890-1910$} & \multicolumn{2}{|c|}{$1920-1933$} \\
\hline & Level & Change & Level & Change & Level & Change & Level & Change \\
\hline First & 0.75 & -0.19 & 0.96 & 0.02 & 0.84 & -0.04 & 0.95 & 0.06 \\
\hline Second & 0.61 & 0.12 & 0.92 & 0.05 & 0.68 & -0.11 & 0.89 & 0.14 \\
\hline Third & 0.40 & -0.20 & 0.86 & -0.10 & 0.57 & -0.05 & 0.82 & 0.04 \\
\hline Fourth & 0.29 & -0.05 & 0.81 & 0.09 & 0.48 & -0.18 & 0.74 & 0.03 \\
\hline Fifth & 0.20 & -0.06 & 0.76 & 0.10 & 0.45 & -0.02 & 0.66 & -0.07 \\
\hline Sixth & 0.14 & -0.09 & 0.70 & 0.06 & 0.42 & 0.01 & 0.58 & -0.02 \\
\hline Seventh & 0.12 & -0.02 & 0.64 & -0.03 & 0.39 & -0.13 & 0.50 & -0.15 \\
\hline Eighth & 0.11 & -0.09 & 0.58 & 0.01 & 0.38 & -0.13 & 0.44 & -0.02 \\
\hline Ninth & 0.13 & 0.02 & 0.52 & -0.10 & 0.42 & 0.02 & 0.37 & -0.00 \\
\hline Tenth & 0.15 & -0.00 & 0.48 & 0.02 & 0.45 & 0.10 & 0.31 & -0.05 \\
\hline Eleventh & 0.17 & 0.06 & 0.42 & -0.03 & 0.45 & -0.01 & 0.25 & 0.00 \\
\hline Twelfth & 0.15 & 0.15 & 0.37 & 0.03 & 0.45 & 0.18 & 0.19 & -0.04 \\
\hline Std. dev. & 1.53 & 1.07 & 2.11 & 0.52 & 1.25 & 0.70 & 1.61 & 0.45 \\
\hline
\end{tabular}

The approximate standard errors for the autocorrelations (under the null that the series is white noise) are 0.06 for the $1890-1910$ sample and 0.08 for the 1920-1933 sample.

Table 2

Regressions of short rate on lagged short rate."

\begin{tabular}{|c|c|c|c|c|c|c|c|c|}
\hline \multirow[b]{3}{*}{ Constant } & \multicolumn{4}{|c|}{ United States } & \multicolumn{4}{|c|}{ Britain } \\
\hline & \multicolumn{2}{|c|}{$1890-1910$} & \multicolumn{2}{|c|}{$1920-1933$} & \multicolumn{2}{|c|}{$1890-1910$} & \multicolumn{2}{|c|}{$1920-1933$} \\
\hline & $\begin{array}{c}1.01 \\
(0.18)\end{array}$ & $\begin{array}{c}0.03 \\
(0.29)\end{array}$ & $\begin{array}{c}0.09 \\
(0.09)\end{array}$ & $\begin{array}{c}0.05 \\
(0.16)\end{array}$ & $\begin{array}{c}0.42 \\
(0.10)\end{array}$ & $\begin{array}{c}0.09 \\
(0.16)\end{array}$ & $\begin{array}{c}0.11 \\
(0.09)\end{array}$ & $\begin{array}{c}0.10 \\
(0.09)\end{array}$ \\
\hline$i_{t-1}$ & $\begin{array}{c}0.75 \\
(0.04)\end{array}$ & $\begin{array}{c}0.77 \\
(0.04)\end{array}$ & $\begin{array}{c}0.97 \\
(0.02)\end{array}$ & $\begin{array}{c}0.98 \\
(0.02)\end{array}$ & $\begin{array}{c}0.84 \\
(0.03)\end{array}$ & $\begin{array}{c}0.86 \\
(0.03)\end{array}$ & $\begin{array}{c}0.96 \\
(0.02)\end{array}$ & $\begin{array}{c}0.97 \\
(0.02)\end{array}$ \\
\hline$d^{2}$ & & $\begin{array}{c}1.05 \\
(0.29)\end{array}$ & & $\begin{array}{c}0.34 \\
(0.19)\end{array}$ & & $\begin{array}{c}0.19 \\
(0.18)\end{array}$ & & $\begin{array}{r}-0.07 \\
(0.17)\end{array}$ \\
\hline$d^{3}$ & & $\begin{array}{c}0.90 \\
(0.29)\end{array}$ & & $\begin{array}{c}-0.10 \\
(0.19)\end{array}$ & & $\begin{array}{c}0.00 \\
(0.18)\end{array}$ & & $\begin{array}{c}-0.23 \\
(0.17)\end{array}$ \\
\hline$d^{4}$ & & $\begin{array}{c}0.55 \\
(0.29)\end{array}$ & & $\begin{array}{c}-0.16 \\
(0.19)\end{array}$ & & $\begin{array}{c}0.39 \\
(0.18)\end{array}$ & & $\begin{array}{r}-0.09 \\
(0.17)\end{array}$ \\
\hline$d^{s}$ & & $\begin{array}{c}0.60 \\
(0.29)\end{array}$ & & $\begin{array}{c}-0.07 \\
(0.19)\end{array}$ & & $\begin{array}{c}-0.08 \\
(0.18)\end{array}$ & & $\begin{array}{c}-0.07 \\
(0.17)\end{array}$ \\
\hline$d^{6}$ & & $\begin{array}{c}0.77 \\
(0.29)\end{array}$ & & $\begin{array}{c}-0.06 \\
(0.19)\end{array}$ & & $\begin{array}{c}-0.20 \\
(0.18)\end{array}$ & & $\begin{array}{c}0.14 \\
(0.17)\end{array}$ \\
\hline$d^{7}$ & & $\begin{array}{c}1.10 \\
(0.29)\end{array}$ & & $\begin{array}{c}0.17 \\
(0.19)\end{array}$ & & $\begin{array}{c}0.60 \\
(0.18)\end{array}$ & & $\begin{array}{c}0.13 \\
(0.17)\end{array}$ \\
\hline$d^{8}$ & & $\begin{array}{c}1.44 \\
(0.29)\end{array}$ & & $\begin{array}{c}0.16 \\
(0.19)\end{array}$ & & $\begin{array}{c}0.48 \\
(0.18)\end{array}$ & & $\begin{array}{c}-0.01 \\
(0.17)\end{array}$ \\
\hline$d^{9}$ & & $\begin{array}{c}1.30 \\
(0.29)\end{array}$ & & $\begin{array}{c}0.12 \\
(0.19)\end{array}$ & & $\begin{array}{c}0.58 \\
(0.18)\end{array}$ & & $\begin{array}{c}0.19 \\
(0.17)\end{array}$ \\
\hline$d^{10}$ & & $\begin{array}{c}1.46 \\
(0.29)\end{array}$ & & $\begin{array}{c}-0.12 \\
(0.19)\end{array}$ & & $\begin{array}{c}1.05 \\
(0.18)\end{array}$ & & $\begin{array}{r}-0.06 \\
(0.17)\end{array}$ \\
\hline$d^{11}$ & & $\begin{array}{c}0.71 \\
(0.29)\end{array}$ & & $\begin{array}{c}-0.12 \\
(0.19)\end{array}$ & & $\begin{array}{c}0.23 \\
(0.18)\end{array}$ & & $\begin{array}{c}0.06 \\
(0.06)\end{array}$ \\
\hline$d^{12}$ & & $\begin{array}{c}1.10 \\
(0.29)\end{array}$ & & $\begin{array}{c}0.17 \\
(0.19)\end{array}$ & & $\begin{array}{c}-0.04 \\
(0.18)\end{array}$ & & $\begin{array}{r}-0.07 \\
(0.17)\end{array}$ \\
\hline $\begin{array}{l}R^{2} \\
\text { s.e.e }\end{array}$ & $\begin{array}{l}0.57 \\
1.00\end{array}$ & $\begin{array}{l}0.62 \\
0.94\end{array}$ & $\begin{array}{l}0.94 \\
0.52\end{array}$ & $\begin{array}{l}0.94 \\
0.51\end{array}$ & $\begin{array}{l}0.71 \\
0.68\end{array}$ & $\begin{array}{l}0.79 \\
0.59\end{array}$ & $\begin{array}{l}0.92 \\
0.45\end{array}$ & $\begin{array}{l}0.92 \\
0.45\end{array}$ \\
\hline
\end{tabular}

"Standard errors are in parentheses. 
evidence of seasonality. In both countries, the short-term nominal interest rate became approximately a random walk.

In fig. 1 we display estimates of the seasonal pattern in short rates for both countries and sample periods. The seasonal patterns were calculated by regressing the short rate on seasonal dummies only, with the coefficients constrained to change smoothly from one month to the next. Specifically, we regressed the short rate on lags one through twelve of the seasonal dummy for January, with the coefficients constrained to follow a fifth order polynomial distributed lag. The figures present the differences of the twelve coefficients from the average coefficient.

The pattern of seasonality is similar in timing across countries. Rates were high in the fall, especially November, and low in the summer, particularly July. The amplitude of the seasonal pattern is also similar, approximately 200
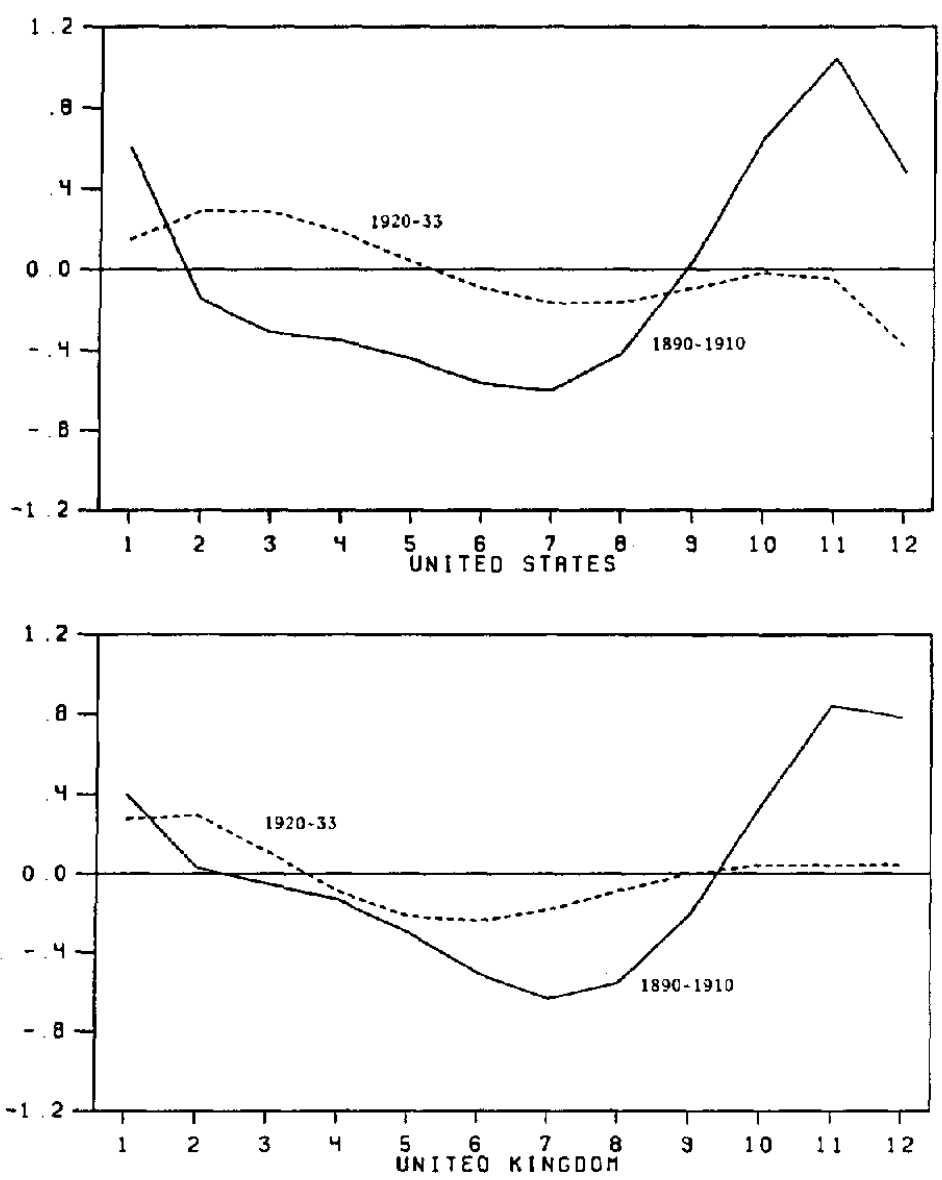

Fig. 1. Seasonal in nominal interest rates. 
basis points (at an annual rate) in both countries. The seasonal pattern is statistically significant in both countries in both sample periods, but in the later sample period the amplitude of the seasonal patterns is much smaller. Tests of the hypothesis that the seasonal patterns are the same before and after 1914 reject the null at the $1 \%$ level for both the United States and Britain. ${ }^{16}$

The next question we address is whether the changes in the behavior of nominal interest rates coincide with changes in the behavior of inflation rates. Tables 3 and 4 present results for the one month inflation rate analogous to those in tables 1 and 2 for the nominal interest rate.

During the early sample period, the autocorrelation function in the United States shows significant correlation at the first lag but little at any other lag. This is exactly the result we would expect if the true inflation process were white noise in continuous time but we employed time average price level data to compute the inflation rates [Working (1960)]. For the United States the price level data are averages over a month, so our results are consistent with a white noise process for the inflation rate. In Britain, there is stronger first order autocorrelation during the early sample period, and several of the higher order autocorrelations are significant. Also, the price data for Britain are allegedly from the last week of each month, so the time-average bias should not be severe. The results therefore indicate some positive serial

Table 3

Autocorrelations of the one month inflation rate."

\begin{tabular}{lccccc}
\hline & \multicolumn{3}{c}{ United States } & \multicolumn{3}{c}{ Britain } \\
\cline { 2 - 3 } \cline { 5 - 6 } & $1890-1910$ & $1920-1933$ & & $1890-1910$ & $1920-1933$ \\
\hline First & 0.18 & 0.65 & 0.32 & 0.46 \\
Second & 0.02 & 0.56 & 0.10 & 0.28 \\
Third & 0.03 & 0.38 & 0.10 & 0.17 \\
Fourth & -0.00 & 0.31 & 0.05 & 0.15 \\
Fifth & -0.02 & 0.13 & 0.05 & 0.10 \\
Sixth & -0.02 & 0.07 & 0.02 & 0.09 \\
Seventh & -0.04 & -0.00 & 0.02 & 0.06 \\
Eighth & 0.05 & -0.04 & 0.15 & 0.09 \\
Ninth & 0.02 & -0.04 & 0.13 & 0.12 \\
Tenth & -0.03 & -0.00 & -0.03 & 0.15 \\
Eleventh & -0.02 & 0.04 & 0.01 & 0.08 \\
Twelfth & -0.09 & -0.04 & -0.02 & -0.09 \\
Std. dev. & 18.95 & 23.08 & 12.02 & 25.47 \\
\hline
\end{tabular}

'The approximate standard errors for the autocorrelations (under the null that the series is white noise) are 0.06 for the $1890-1910$ sample and 0.08 for the 1920-1933 sample.

\footnotetext{
${ }^{16}$ The hypothesis tests were carried out on the seasonal dummy coeflicients in the change in the short rate because the level is probably non-stationary in the second sample period. The tests were performed on the OLS estimates of seasonal dummy coefficients, with the standard errors corrected using the Hansen and Hodrick (1980) procedure [as modilied by Newey and West (1987)]. The lag length used to calculate the variance-covariance matrix was 12.
} 
Table 4

Regressions of inflation rate on lagged inflation rate.

\begin{tabular}{|c|c|c|c|c|c|c|c|c|}
\hline \multirow[b]{3}{*}{ Constant } & \multicolumn{4}{|c|}{ United States } & \multicolumn{4}{|l|}{ Britain } \\
\hline & \multicolumn{2}{|c|}{$1890-1910$} & \multicolumn{2}{|c|}{$1920-1933$} & \multicolumn{2}{|c|}{$1890-1910$} & \multicolumn{2}{|c|}{$1920-1933$} \\
\hline & $\begin{array}{c}0.73 \\
(1.19)\end{array}$ & $\begin{array}{c}-2.90 \\
(4.07)\end{array}$ & $\begin{array}{r}-1.65 \\
(1.39)\end{array}$ & $\begin{array}{c}2.22 \\
(4.65)\end{array}$ & $\begin{array}{c}0.29 \\
(0.72)\end{array}$ & $\begin{array}{c}0.90 \\
(2.44)\end{array}$ & $\begin{array}{c}-4.01 \\
(1.80)\end{array}$ & $\begin{array}{c}4.34 \\
(5.97)\end{array}$ \\
\hline$\pi_{1-1}$ & $\begin{array}{c}0.18 \\
(0.06)\end{array}$ & $\begin{array}{c}0.17 \\
(0.06)\end{array}$ & $\begin{array}{c}0.66 \\
(0.06)\end{array}$ & $\begin{array}{c}0.68 \\
(0.06)\end{array}$ & $\begin{array}{c}0.32 \\
(0.06)\end{array}$ & $\begin{array}{c}0.36 \\
(0.06)\end{array}$ & $\begin{array}{c}0.47 \\
(0.07)\end{array}$ & $\begin{array}{c}0.50 \\
(0.07)\end{array}$ \\
\hline$d^{2}$ & & $\begin{array}{c}6.46 \\
(5.76)\end{array}$ & & $\begin{array}{c}-4.33 \\
(6.54)\end{array}$ & & $\begin{array}{c}-2.99 \\
(3.45)\end{array}$ & & $\begin{array}{r}-12.66 \\
(8.44)\end{array}$ \\
\hline$d^{3}$ & & $\begin{array}{c}2.14 \\
(5.76)\end{array}$ & & $\begin{array}{c}-1.92 \\
(6.54)\end{array}$ & & $\begin{array}{c}2.61 \\
(3.56)\end{array}$ & & $\begin{array}{c}-7.11 \\
(8.43)\end{array}$ \\
\hline$d^{4}$ & & $\begin{array}{c}-4.63 \\
(5.76)\end{array}$ & & $\begin{array}{c}-4.90 \\
(6.54)\end{array}$ & & $\begin{array}{c}1.14 \\
(3.45)\end{array}$ & & $\begin{array}{r}-14.98 \\
(8.43)\end{array}$ \\
\hline$d^{5}$ & & $\begin{array}{c}4.34 \\
(5.76)\end{array}$ & & $\begin{array}{c}7.84 \\
(6.54)\end{array}$ & & $\begin{array}{c}-9.04 \\
(3.45)\end{array}$ & & $\begin{array}{r}-16.49 \\
(8.45)\end{array}$ \\
\hline$d^{6}$ & & $\begin{array}{l}10.28 \\
(5.76)\end{array}$ & & $\begin{array}{c}-7.05 \\
(6.60)\end{array}$ & & $\begin{array}{c}3.78 \\
(3.49)\end{array}$ & & $\begin{array}{c}5.06 \\
(8.48)\end{array}$ \\
\hline$d^{7}$ & & $\begin{array}{l}11.49 \\
(5.78)\end{array}$ & & $\begin{array}{c}-0.14 \\
(6.55)\end{array}$ & & $\begin{array}{c}0.29 \\
(3.45)\end{array}$ & & $\begin{array}{r}-12.84 \\
(8.43)\end{array}$ \\
\hline$d^{8}$ & & $\begin{array}{c}6.78 \\
(5.79)\end{array}$ & & $\begin{array}{r}-13.50 \\
(6.57)\end{array}$ & & $\begin{array}{c}-0.03 \\
(3.45)\end{array}$ & & $\begin{array}{c}-4.95 \\
(8.43)\end{array}$ \\
\hline$d^{9}$ & & $\begin{array}{c}-0.64 \\
(5.77)\end{array}$ & & $\begin{array}{c}-6.02 \\
(6.53)\end{array}$ & & $\begin{array}{c}-0.16 \\
(3.45)\end{array}$ & & $\begin{array}{r}-10.21 \\
(8.43)\end{array}$ \\
\hline$d^{10}$ & & $\begin{array}{c}5.77 \\
(5.76)\end{array}$ & & $\begin{array}{r}-10.17 \\
(6.53)\end{array}$ & & $\begin{array}{c}-4.88 \\
(3.45)\end{array}$ & & $\begin{array}{c}-5.13 \\
(8.43)\end{array}$ \\
\hline$d^{11}$ & & $\begin{array}{c}-0.37 \\
(5.76)\end{array}$ & & $\begin{array}{r}-1.66 \\
(6.54)\end{array}$ & & $\begin{array}{c}-0.72 \\
(3.47)\end{array}$ & & $\begin{array}{r}-13.83 \\
(8.43)\end{array}$ \\
\hline$d^{12}$ & & $\begin{array}{c}2.10 \\
(5.76)\end{array}$ & & $\begin{array}{c}-3.64 \\
(6.53)\end{array}$ & & $\begin{array}{c}2.56 \\
(3.45)\end{array}$ & & $\begin{array}{c}-4.77 \\
(8.44)\end{array}$ \\
\hline $\begin{array}{l}R^{2} \\
\text { s.e.e. }\end{array}$ & $\begin{array}{l}0.029 \\
18.8\end{array}$ & $\begin{array}{l}0.045 \\
18.7\end{array}$ & $\begin{array}{l}0.433 \\
17.5\end{array}$ & $\begin{array}{l}0.447 \\
17.3\end{array}$ & $\begin{array}{l}0.098 \\
11.4\end{array}$ & $\begin{array}{l}0.139 \\
11.3\end{array}$ & $\begin{array}{l}0.219 \\
22.4\end{array}$ & $\begin{array}{l}0.228 \\
22.3\end{array}$ \\
\hline
\end{tabular}

-Standard errors are in parentheses.

correlation in the inflation rate for Britain. In the post-1914 sample period there is modest but clearly significant persistence in the inflation rate in both countries.

The regression results tell essentially the same story as the autocorrelations. In the United States there is little indication of persistence in the inflation rate in the early sample period but clear evidence of such persistence in the later sample. In Britain, there is some indication of persistence in the first sample and modest but significant persistence in the later sample.

We display estimates of the seasonal patterns in inflation in fig. $2 .^{17}$ The estimates indicate substantial seasonality in the inflation rate in both

${ }^{17}$ These were calculated by regressing the inflation rates on seasonal dummies whose coefficients were constrained to follow a lifth order polynomial, as above. 

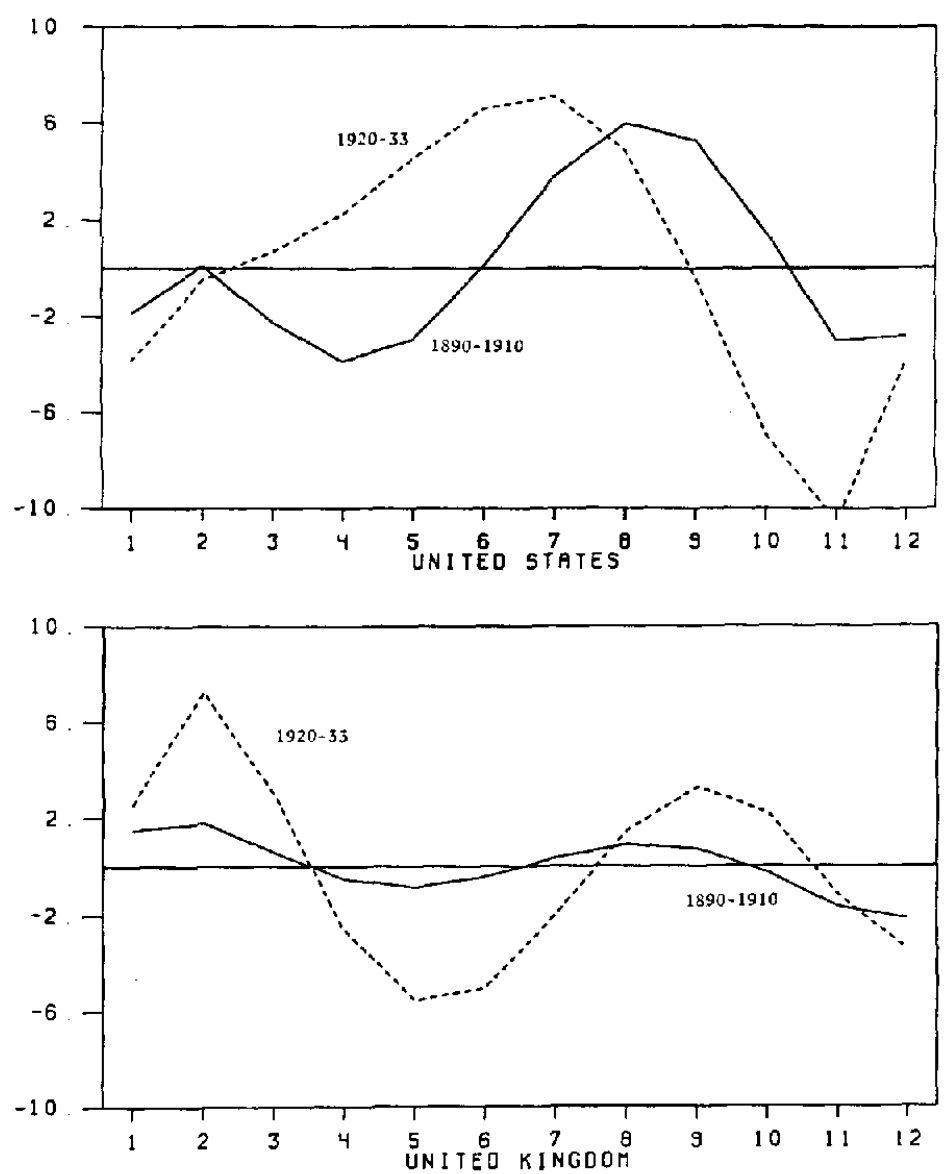

Fig. 2. Seasonal in inflation rates.

countries in both time periods: the amplitude of the seasonal is at least 800 basis points in every sample and more than 2000 basis points in the later samples. The seasonal in the inflation rate is significantly different from zero in all four samples. Although the point estimates suggest that there are significant differences in the seasonal patterns across sample periods, tests of the hypothesis of no change fail to reject the null at even the $35 \%$ level for either country. ${ }^{18}$

The results presented above clearly delineate the change in the stochastic processes for interest rates and prices. In both countries there is increased persistence in both the short term nominal interest rate and the inflation rate, and there is markedly decreased seasonality in the interest rate. One

\footnotetext{
${ }^{18}$ The test statistics refer to OLS estimates of the seasonal dummy coefficients, with standard errors computed using the Hansen and Hodrick (1980) procedure.
} 
cannot determine whether there are significant changes in the seasonal patterns in inflaton rates. Although the changes that occur in both variables are qualitatively similar across countries, the changes are more pronounced in the United States.

\section{A model of policy interaction under a gold standard}

The traditional explanation of the changes in the behavior of interest rates and prices in the United States is that the changes were due to the founding of the Federal Reserve System. Certainly a reader of contemporary periodicals would be drawn to this explanation. As we have discussed, the Fed was created primarily to stabilize interest rates and credit markets, so it should not be surprising that interest rates stabilized after its founding. The fact that the change in the behavior of interest rates and prices occurred worldwide, however, calls this traditional explanation into question. One might also make the a priori argument that under a fixed exhange rate system, as existed before 1914, the existence of the Fed should be irrelevant. Under fixed exchange rates, international arbitrage should equate nominal interest rates throughout the world. Therefore, the introduction of a single central bank, such as the Federal Reserve, should have at most minimal effects on interest rates or prices.

The assertion that the Fed could not have been responsible for the changes in the behavior of interest rates and prices obviously raises the question of what did cause these changes. The most obvious alternative explanation is that the changes were caused by the breakdown of the classical gold standard and the fixed exchange rate system at the beginning of World War I. Indeed, it might seem difficult to make an affirmative case for the position that the breakdown of the classical gold standard was not relevant to the changes in the behavior of interest rates and prices.

The purpose of this section is to make theoretically plausible the position that the Fed could have been the cause of the changes in the behavior of interest rates and prices. We consider a historical counterfactual. In particular, we argue that the founding of the Fed might have led to the changed behavior of interest rates and prices, even if World War I and the breakdown of the classical gold standard had not occurred. Of course, no purely theoretical discussion can preclude a possibly important role for the destruction of the gold standard in causing the changes in financial markets. Theory can, however, overturn the presumption that the changes could not have been due to the Fed. We turn in Section $V$ to an evaluation of the part played by each of these two events in bringing about the observed changes in the behavior of interest rates and prices.

\subsection{The set-up of the model}

We propose a simple model in which exchange rates are fixed and in which the introduction of a single central bank might have worldwide 
implications for interest rates and prices. ${ }^{19}$ The model is highly stylized. It assumes perfect capital markets, perfect purchasing power parity, and a complete dichotomy between real and monetary phenomena. These assumptions are probably incorrect and perhaps patently false. We nonetheless believe the model is useful as an illustration of some of the forces that might have been at work. In particular, the model allows us to show that the introduction of a central bank in one country might have worldwide implications.

Consider a world of two identical countries operating under fixed exchange rates. Each country wishes to stabilize its nominal interest rate and to avoid international gold flows. When there is a central bank in only one country, it is impossible for that central bank to both stabilize interest rates and avoid gold flows. Hence, that bank must trade off the two goals. Once the second country introduces a central bank, both banks can together stabilize interest rates without generating undesirable gold flows. This equilibrium with two central banks achieves the first-best monetary policy, even in the absence of coordination.

In each country, the demand for money is given by the simple quantity equation

$$
\begin{aligned}
& M_{t}=P_{t}, \\
& M_{i}^{*}=P_{t}^{*},
\end{aligned}
$$

where $M$ is the country's quantity of money, $P$ is the price of goods in terms of money, and a star denotes a foreign country variable. Because we assume purchasing power parity, $P=P^{*}$.

The supply of money is assumed to consist of monetary gold and fiduciary money - that is, money printed by the central bank that is (in principle) convertible into gold and thus trades one-for-one with gold. The world supply of money is

$$
M_{t}+M_{t}^{*}=M_{t-1}+M_{t-1}^{*}+X_{t}+X_{t}^{*},
$$

where $X$ is the quantity of new fiduciary money printed. We assume that the bank changes the quantity of fiduciary money within sufficiently narrow bounds that the maintenance of the gold standard is not threatened. ${ }^{20}$

There is an exogenous real interest rate, $r_{t}$, that is common across countries. The nominal rate, $i_{\text {, }}$, is

$$
i_{t}=r_{t}+\pi_{t},
$$

\footnotetext{
${ }^{19} \mathrm{~A}$ similar model is presented in Eichengreen (1984). That model does not focus on interest rate stabilization, however.

${ }^{20}$ See Shiller and Seigel (1977) on the Bank of England.
} 
where $\pi_{\mathrm{t}}$ is the world inflation rate. From the simple money demand equations, we know

$$
\pi_{\mathrm{t}}=\frac{M_{t}-M_{t-1}}{M_{t-1}}=\frac{M_{\mathrm{t}}^{*}-M_{t-1}^{*}}{M_{t-1}^{*}} .
$$

The rate of inflation equals the rate of money growth in each country.

The central banks have two objectives: to achieve a nominal interest rate target and to avoid flows of gold between countries. Define

$$
\begin{aligned}
& f_{t}=\frac{M_{t-1}+X_{t}-M_{t}}{M_{t-1}}, \\
& f_{t}^{*}=\frac{M_{t-1}^{*}+X_{t}^{*}-M_{t}^{*}}{M_{t-1}^{*}}, \quad \text { and } \\
& x_{t}=\frac{X_{t}}{M_{t-1}}, \\
& x_{t}^{*}=\frac{X_{t}^{*}}{M_{t-1}^{*}} .
\end{aligned}
$$

The quantities $f_{t}$ and $f_{t}^{*}$ are the percentage net outflows of gold between the two countries, while the quantities $x_{t}$ and $x_{t}^{*}$ are the percentage production of new fiduciary money.

The choice variables for the two central banks can be viewed as $x$ and $x^{*}$. Straightforward algebra verifies that

$$
\begin{aligned}
& i_{\mathrm{t}}=r_{t}+\frac{1}{2}\left(x_{\mathrm{t}}+x_{t}^{*}\right), \quad \text { and } \\
& f_{t}=-f_{t}^{*}=\frac{1}{2}\left(x_{\mathrm{t}}-x_{t}^{*}\right) .
\end{aligned}
$$

The first equation says that the nominal interest rate depends on the exogenous real interest rate and the average rate of money creation in the two countries. The second equation says that the amount of gold flow between the two countries depends on the difference between the amounts of money creation.

\subsection{The solution with one central bank}

Consider first the situation in which only the home country has a central bank. In this case, $x^{*}=0$. The home country has one choice variable, $x$, which affects both the interest rate $i$ and the amount of gold flow $f$. 
Suppose the objective of the central bank is to minimize

$$
V=\left(i_{t}-\bar{i}_{t}\right)^{2}+\phi f_{t}^{2} .
$$

That is, the central bank dislikes gold flows, and would like to stick close to a target nominal interest rate $\vec{i}_{r}{ }^{21}$ It faces the constraints

$$
\begin{aligned}
& i_{t}=r_{t}+\frac{1}{2} x_{t}, \quad \text { and } \\
& f_{t}=\frac{1}{2} x_{r} .
\end{aligned}
$$

Minimizing $V$ subject to these constraints yields

$$
\begin{aligned}
& x_{t}=\frac{2}{1+\phi}\left(\bar{i}_{t}-r_{t}\right), \\
& f_{t}=\frac{1}{1+\phi}\left(\bar{i}_{t}-r_{t}\right), \\
& i_{t}=\frac{1}{1+\phi} \bar{i}_{t}+\frac{\phi}{1+\phi} r_{t} .
\end{aligned}
$$

Note that for large $\phi$, the central bank embarks on no policy at all, since doing so generates highly undesirable gold flows. In this limiting case, the nominal interest rate simply equals the exogenous real interest rate.

\subsection{The solution with two central banks}

Consider now a situation with two central banks. Each central bank has the same objective function and takes the other central bank's creation of money $\left(x\right.$ or $\left.x^{*}\right)$ as given. Thus, we are solving for the Nash equilibrium of the policy game. (Given the assumed commonality of objectives, the gametheoretic aspects are not of great interest.)

The home country's reaction function, determined by choosing $x$ to minimize $V$ for a given $x^{*}$, is

$$
x_{t}=\frac{2}{1+\phi}\left(\bar{i}_{t}-r_{t}\right)+\frac{\phi-1}{\phi+1} x_{t}^{*},
$$

\footnotetext{
${ }^{21}$ The bank dislikes gold outflows because they threaten the bank's ability to maintain convertibility. It dislikes gold inflows (probably to a lesser degree) because of the resource cost of holding an excessive quantity of reserves and because the accumulation of gold by the home central bank implies a greater likelihood of a convertibility crisis in some other country. See Mankiw (1987) for an optimal tax justification of the bank's nominal interest rate target.
} 
and the foreign country's reaction function is

$$
x_{t}^{*}=\frac{2}{1+\phi}\left(\bar{i}_{t}-r_{t}\right)+\frac{\phi-1}{\phi+1} x_{t} .
$$

The Nash equilibrium is therefore

$$
x_{t}=x_{i}^{*}=\bar{i}_{i}-r_{t},
$$

and the equilibrium values of the endogenous variables are

$$
\begin{aligned}
& i_{\mathrm{t}}=\bar{i}_{t}, \\
& f_{t}=0 .
\end{aligned}
$$

Thus, in the equilbrium with two central banks, there are no gold flows, and the nominal interest rate always equals its target. ${ }^{22}$

\subsection{Discussion}

At the broad brush level, the model outlined above provides a basis for attributing the changes in the behavior of interest rates and prices to the founding of the Federal Reserve, rather than to the dissolution of the gold standard. With this model as background, we can interpret the historical events in the following way. Before 1914, all countries had both an interest rate target and a desire to minimize gold flows. Because the United States had no central bank, however, and because most countries with central banks placed significant weight on their desire to prevent gold flows, it was not optimal for any central bank to attempt to smooth its country's interest rate. After 1914, when the Fed was introduced, it was desirable for each central bank to stabilize rates, knowing that all other banks would do likewise. As a result, interest rates were stabilized. This explanation of the changes in the behavior of interest rates and prices gives no role to the destruction of the gold standard. The explanation also provides a basis for believing that the founders of the Fed were rational in thinking that the introduction of the Fed would stabilize interest rates in the United States, even if the world continued to operate on a gold standard.

\footnotetext{
${ }^{22}$ With an arbitrary nominal interest peg, $\bar{i}_{t}$, the implied inflation rate may not be compatible with the long run maintenance of the gold standard. The time subscript indicates that the central bank periodically revises its interest rate target with this consideration in mind. Even though the bank cannot set the long run nominal rate arbitrarily, however, it can still offset seasonal and other transitory disturbances.
} 


\section{What was responsible: The Fed or the gold standard?}

One implication of the line of reasoning in the last section is that the dissolution of the gold standard and the founding of the Federal Reserve might have been, to some extent, hypothetical substitutes. Both would tend to have the effect of removing the need to avoid gold flows as a dominant objective of monetary policy, allowing the domestic consideration of interest rate smoothing to come to the forefront. The counterfactual that we entertained in our theoretical example of policy coordination imagined the operation of the Federal Reserve, in addition to other countries' central banks, within the context of a continuing gold standard. We concluded that interest rate stabilization in each country would have been an admissible equilibrium outcome in that scenario.

A second counterfactual worth entertaining is to suppose that the gold standard had been suspended, but no Federal Reserve had been established. Although the freedom from international constraints regarding gold flows would certainly have been achieved, it is by no means clear how, in the absence of a central bank, the United States could have taken advantage of this freedom to stabilize interest rates. We are not aware of a well-articulated story in which the dissolution of a gold standard, in and of itself, would lead to smoothed interest rates. This observation makes us suspicious that the break with gold, unaccompanied by the introduction of the Fed, would have done the job. However, some more concrete evidence on the roles of the two historical events is needed. In this section we present information that allows us to evaluate whether the Fed or the destruction of the gold standard was more likely responsible for the changes in financial markets.

Before turning to that evidence, we address briefly the issue of whether World War I per se, or some other unspecified event, might have been responsible for the changes in the behavior of interest rates and prices. We note first that the changes we have documented above appear to have occurred well before 1920. When we compute results for the period 19151918 , we find that this period appears qualitatively much more like the 19201933 period than like the 1890-1910 period. The changes that occurred in financial markets were clearly present during Word War I and continued, in even more dramatic form, after the end of the War. This indicates that the War in and of itself was not the source of the changes. As a second piece of evidence that either the Fed or the gold standard was responsible for the changes, we have examined the switching regressions analogous to those in Mankiw, Miron and Weil (1987) that allow us to date the most likely point of the changes in the stochastic processes. We find that for both interest rates and inflation the switch occurred with high probability sometime between the middle of 1914 and the middle of 1915 in both the United States and Britain. Thus, the results support the notion that either the dismantling of the gold standard or the founding of the Fed, rather than some other 
unspecified event, was responsible for the changes observed in the stochastic behavior of interest rates and prices. ${ }^{23}$

We now turn to evaluating the roles of the two major changes in institutions. Our first piece of evidence comes from examining a different historical example of a switch from fixed to flexible exchange rates. Tables 5 and 6 present autocorrelations of the short rate and the inflation rate for the

Table 5

Autocorrelations of the short rate.

\begin{tabular}{|c|c|c|c|c|c|c|c|c|}
\hline & \multicolumn{4}{|c|}{ United States } & \multicolumn{4}{|l|}{ Britain } \\
\hline & \multicolumn{2}{|c|}{ 1957-1969 } & \multicolumn{2}{|c|}{$1974-1984$} & \multicolumn{2}{|c|}{$1957-1969$} & \multicolumn{2}{|c|}{$1974-1984$} \\
\hline & Level & Change & Level & Change & Level & Change & Level & Change \\
\hline First & 0.95 & 0.21 & 0.95 & 0.09 & 0.94 & 0.11 & 0.94 & 0.11 \\
\hline Second & 0.90 & 0.05 & 0.87 & -0.09 & 0.86 & 0.04 & 0.87 & 0.13 \\
\hline Third & 0.84 & 0.15 & 0.84 & -0.05 & 0.78 & -0.09 & 0.79 & -0.04 \\
\hline Fourth & 0.78 & -0.04 & 0.79 & -0.14 & 0.71 & 0.01 & 0.71 & -0.12 \\
\hline Fifth & 0.72 & -0.07 & 0.76 & 0.01 & 0.64 & 0.05 & 0.65 & 0.12 \\
\hline Sixth & 0.67 & -0.06 & 0.72 & -0.19 & 0.56 & -0.07 & 0.57 & 0.01 \\
\hline Seventh & 0.63 & -0.27 & 0.71 & -0.15 & 0.49 & -0.14 & 0.49 & -0.03 \\
\hline Eighth & 0.60 & -0.11 & 0.71 & 0.15 & 0.43 & -0.24 & 0.42 & -0.09 \\
\hline Ninth & 0.58 & 0.02 & 0.70 & 0.08 & 0.40 & -0.10 & 0.35 & 0.00 \\
\hline Tenth & 0.55 & -0.10 & 0.68 & 0.10 & 0.38 & -0.10 & 0.28 & -0.22 \\
\hline Eleventh & 0.53 & -0.01 & 0.64 & 0.10 & 0.38 & -0.04 & 0.24 & -0.03 \\
\hline Twelfth & 0.50 & 0.11 & 0.60 & -0.21 & 0.38 & 0.03 & 0.20 & -0.04 \\
\hline Std. dev. & 1.32 & 0.27 & 2.95 & 0.95 & 1.38 & 0.44 & 2.53 & 0.84 \\
\hline
\end{tabular}

Table 6

Autocorrelations of the one month inflation rate."

\begin{tabular}{lccccc}
\hline & United States & \multicolumn{3}{c}{ Britain } \\
\cline { 2 - 3 } \cline { 5 - 6 } & $1957-1969$ & $1974-1984$ & & $1957-1969$ & $1974-1984$ \\
\hline First & 0.17 & 0.44 & -0.15 & 0.58 \\
Second & 0.13 & 0.28 & 0.11 & 0.53 \\
Third & -0.12 & 0.43 & 0.15 & 0.48 \\
Fourth & 0.08 & 0.13 & 0.02 & 0.40 \\
Fifth & 0.09 & 0.23 & 0.09 & 0.33 \\
Sixth & 0.19 & 0.24 & 0.01 & 0.39 \\
Seventh & 0.01 & 0.02 & 0.09 & 0.28 \\
Eighth & 0.07 & 0.12 & 0.02 & 0.32 \\
Ninth & 0.09 & 0.26 & -0.02 & 0.36 \\
Tenth & 0.18 & 0.14 & 0.06 & 0.29 \\
Eleventh & 0.05 & 0.19 & 0.05 & 0.35 \\
Twelfth & 0.12 & 0.26 & 0.07 & 0.40 \\
Std. dev. & 3.76 & 8.35 & 4.62 & 7.35 \\
\hline
\end{tabular}

"The approximate standard errors for the autocorrelations (under the null that the series is white noise) are 0.08 for the 1957-1969 sample and 0.09 for the 1974-1984 sample.

${ }^{23} \mathrm{As}$ far as distinguishing between these two possibilities, however, we find the results of such dating to be inconclusive. The two events simply occurred too close together for this approach to produce conclusive results. 
sample periods 1957-1969 and 1974-1984. The first sample period ends before the breakdown of the Bretton Woods fixed rate regime while the second begins after initiation of the current flexible rate period. ${ }^{24}$

The resuits allow us to make two points. First, seasonal or other transitory variation in interest rates did not return in either country when the world returned to a system of fixed exchange rates. The 1957-69 period exhibits essentially none of the mean reverting variation in interest rates displayed by the 1890-1910 period. Second, the change from fixed to flexible rates in the early 1970s was accompanied by at most minor changes in the persistence of interest rates in each of the two countries. ${ }^{25}$ If the exchange rate regime rather than the Fed was the key consideration in 1914, we would expect to see some signs of similar changes in the interest rate process accompanying the inception and demise of the Bretton Woods regime.

The evidence on inflation shows that the degree of persistence during the Bretton Woods period is more like the pre-Fed period than the 1920-33 period. Also, the increased persistence of inflation at the demise of Bretton Woods mimics the increased persistence after 1914 and is thus more suggestive of the importance of the exchange rate regime than is the evidence from interest rates. It is worth noting that for both the 1957-1969 and 1974 1984 periods the autocorrelations in the WPI inflation rate reported here are noticeably lower than those using the CPI inflation rate [Barsky (1987)].

The second and perhaps more important piece of evidence on the relative role of the Fed and the exchange rate regime appears in tables 7 and 8 ,

Table 7

Correlations across countries in interest rates.

\begin{tabular}{lll}
\hline & $1890-1910$ & $1920-1933$ \\
\hline Level & 0.627 & 0.790 \\
One month change & 0.311 & 0.162 \\
Three month change & 0.545 & 0.375 \\
Six month change & 0.650 & 0.554 \\
\hline
\end{tabular}

Table 8

Correlations across countries in prices.

\begin{tabular}{lll}
\hline & $1890-1910$ & $1920-1933$ \\
\hline Price level & 0.870 & 0.943 \\
One month inflation & 0.347 & 0.447 \\
Three month inflation & 0.539 & 0.626 \\
Six month inflation & 0.540 & 0.687
\end{tabular}

${ }^{24}$ The data series that we use for these calculations are monthly observations on the three month United States and British Treasury bill rates (both taken from the first week of each month) and monthly observations on the United States and British WPI's. We begin the early sample period in 1957 because that is when WPI data for Britain are first available.

${ }^{25}$ There are clear increases in the volatility of the change in interest rates, in contrast to the results for 1914 . 
which show the correlations across countries in price levels, inflation rates, the level of interest rates, and changes in interest rates for the pre-1914 and post-1914 sample periods. To a first approximation, there is little change in these cross-country correlations across sample periods. If anything, inflation rates show more correlation across countries in the flexible rate period, contrary to the usual expectation based on purchasing power parity considerations.

If we ask what contribution the suspension of a gold standard could have made to interest rate stabilization, it appears that any answer must involve a freeing of domestic interest rates and price levels from the international constraints posed by fixed exchange rates. Yet the breakdown of the gold standard in 1914 was not accompanied by an observed change in the international linkages of prices and interest rates. Of course, these crosscountry correlations are properties of reduced form relationships, and it is possible that two very different structures could have lead to similar reduced form observations. Nevertheless, there is nothing in the data to suggest that the within-country changes in prices and interest rates were the result of any reduction in international linkages of interest rates and prices associated with the switch in the exchange rate regime.

In tables 9 and 10 we present the correlations across countries for the Bretton Woods and recent flexible exchange rate periods. There is no evidence that the change in exchange rate regime coincided with a change in the extent to which interest rates and prices move together, confirming the results in Mankiw (1986). This surprising finding warrants investigation in future work.

Table 9

Correlations across countries in interest rates.

\begin{tabular}{lll}
\hline & $1957-1969$ & $1974-1984$ \\
\hline Level & 0.651 & 0.544 \\
One month change & 0.018 & 0.071 \\
Three month change & 0.075 & 0.152 \\
Six month change & 0.041 & 0.176 \\
\hline
\end{tabular}

Table 10

Correlations across countries in prices.

\begin{tabular}{lll}
\hline & $1957-1969$ & $1974-1984$ \\
\hline Price level & 0.911 & 0.986 \\
One month inflation & 0.080 & 0.263 \\
Three month inflation & 0.297 & 0.308 \\
Six month inflation & 0.554 & 0.328 \\
\hline
\end{tabular}




\section{The behavior of real interest rates before and after 1914}

Any discussion of interest rate stabilization would be incomplete without asking whether the stabilization of the nominal rate was accompanied by a change in the process followed by real rates. We take up this question now. We focus on the seasonal movements in real rates because seasonality is an identifiable source of predictable variation in the nominal rate prior to 1914 that is clearly absent in the second sample period. As noted by Shiller (1980), the question thus becomes whether the disappearance of the seasonal in nominal rates was offset by a change in the inflation seasonal so that the seasonal pattern of the underlying expected real rate remained invariant.

We follow the procedure of regressing ex post real rates on twelve dummies for the periods $1890-1910$ and $1920-1933 .{ }^{26}$ As Mishkin (1981) shows, this procedure provides consistent estimates of the seasonal in the ex ante real rate. Since unanticipated inflation adds noise, however, this seasonal pattern will be estimated less precisely than if we had direct measures of the expected real rate. There is a significant real rate seasonal at the $10 \%$ (but not the $5 \%$ level for both countries in the earlier period. The later periods shows no statistically significant evidence of a real rate seasonal in either country, suggesting that there might have been a significant change in the seasonal in the real rate process. Tests of the hypothesis of no change, however, do not reject the null at any conventional significance level. We are forced to conclude, along with Shiller (1980), that the data do not allow any convincing inference about the change in the behavior of real rates.

Our results do make the conclusion stated in Shiller (1980) more convincing. Shiller employs an interest rate series of questionable reliability (the 4-6 month commercial paper rate), and he merely examines plots of estimated seasonal patterns without carrying out hypothesis tests. In addition, the definition of seasonality that he employs (Census X-11) is inappropriate since the seasonal coefficients produced by this technique for any particular year are functions of the data for both sample periods. We have used a more accurate data series and a more appropriate statistical technique, in addition to computing results for an additional country. Thus, although our conclusion is identical to Shiller's, our evidence should help remove any residual doubt about the validity of his conclusion.

\section{Conclusion}

The purpose of this paper has been to evaluate the role of two major institutional changes in contributing to observed changes in the behavior of interest rates and prices after 1914. The paper's contribution lies in showing that the simultaneity of the changes in the processes for interest rates and

\footnotetext{
${ }^{26}$ Again, the standard errors are computed using the Hansen and Hodrick (1980) procedure.
} 
prices in many countries does not, by itself, prove that the changes were due to the destruction of the gold standard rather than to the founding of the Fed. Our model of policy coordination provides an example in which the introduction of the Fed leads to a stabilization of interest rates, even if the gold standard remains intact, and our empirical evidence suggests that the gold standard did not play a crucial role in precipitating the changes in interest rate behavior.

\section{References}

Andrew, A. Piatt, 1907, The treasury and the banks under secretary Shaw, Quarterly Journal of Economics 21, no. 3, Aug., 529-568.

Bagehot, Walter, 1873, Lombard Street (Scribner, New York).

Barro, Robert J., 1987, Interest-rate smoothing, Unpublished manuscript (University of Rochester, Rochester, NY).

Barsky, Robert B., 1987, The Fisher hypothesis and the forecastability and persistence of inflation, Journal of Monetary Economics 19, no. 1, Jan., 3-24.

Bloomfield, Arthur 1., 1959, Monetary policy under the international gold standard: 1880-1914 (Federal Reserve Bank of New York, New York).

Bordo, Michael D. and Anna J. Schwartz, 1984, eds., A retrospective on the classical gold standard (Chicago University Press, Chicago, IL).

Brown, William Adams, Jr., 1940. The international gold standard reinterpreted (National Bureau of Economic Research, New York).

Canova, Fabio, 1987, Seasonality, the creation of the Fed and financial panics: A reinterpretation, Manuscript (University of Minnesota, Minneapolis, MN).

Clark, Truman, 1986, Interest rate seasonals and the Federal Reserve, Journal of Political Economy 94, no. 1, Feb., 76-125.

Cunliffe Committee, 1918, First interim report (London).

Eichengreen, Barry, 1984, International policy coordination in historical perspectives, Discussion paper no. 1081 (Harvard University, Cambridge, MA).

Eichengreen, Barry, 1985, Editor's introduction, in: Barry Eichengreen, ed., The gold standard in theory and history (Methuen, New York).

Friedman, Milton and Anna J. Schwartz, 1963, A monetary history of the United States, 18671960 (Princeton University Press, Princeton, NJ).

Fuller, Wayne A., 1976, Introduction to statistical time series (Wiley, New York).

Gendreau, Brian C., 1979, Bankers' balances, demand deposit interest, and agricultural credit before the banking act of 1933, Journal of Money, Credit, and banking 11, no. 4, Nov., 506-514.

Gendreau, Brian C., 1983, The implicit return on bankers' balances, Journal of Money, Credit, and Banking 15 , no. 4, Nov., 411-424.

Glass, Carter, 1927, An adventure in constructive finance (Doubleday, Page and Co., New York).

Hansen, Lars P. and Robert J. Hodrick, 1980, Forward rates as optimal predictors of future spot rates: An econometric analysis, Journal of Political Economy 88, no. 5, Oct., 829-853.

Jevons, William Stanley, 1884, On the frequent autumnal pressure in the money markel, and the action of the Bank of England, in: Investigations in currency and finance (Macmillan, London).

Keynes, John M., 1923, A tract on monetary reform (Macmillan, London).

Laughlin, J. Laurence, 1912, Banking reform (National Citizens League for the Promotion of a Sound Banking System, Chicago, IL).

Macauley, Frederick, 1938, Some theoretical problems suggested by the movements of interest rates, bond yields, and stock prices in the United States since 1856 (National Bureau of Economic Research, New York).

Mankiw, N. Gregory, 1986, The term structure of interest rates revisited, Brooking Papers on Economic Activity 1, 61-96. 
Mankiw, N. Gregory. 1987, The optimal collection of seignorage: Theory and evidence. Journal of Monetary Economics, Sept., 327-341.

Mankiw, N. Gregory and Jeffrey A. Miron, 1986. The changing behavior of the term structure of interest rates, Quarterly Journal of Economics Cl, no. 2, May, 211-228.

Mankiw, N. Gregory, Jeffrey A. Miron and David N. Weil, 1987, The adjustment of expectations to a change in regime: A study of the founding of the federal reserve, American Economic Review, June, 358-374.

Miron, Jeffrey A., 1986. Financial panics, the seasonality of the nominal interest rate, and the founding of the Fed, American Economic Review 76, no. 1, Mar., 125-140.

Mishkin, Frederic S., 1981, The real rate: An empirical investigation, Carnegie-Rochester Conference Series on Public Policy (North-Holland, Amsterdam) Vol. 12, 519-541.

Morgenstem, Oskar, 1959, International financial transactions and business cycles (Princeton University Press, Princeton, NJ).

Newey, Whitney K. and Kenneth D. West, 1987, A simple, positive semi-definite, heteroskedasticity and autocorrelation consistent covariance matrix, Econometrica 55, 703-708.

Sargent, Thomas J,, 1986, Rational expectations and inflation (Harper and Row, New York).

Sayers, Richard S., 1936, Bank of England operations, 1890-1914 (P.S. King, London).

Shiller, Robert J., 1980, Can the Fed control real interest rates?, in: Stanley Fischer, ed., Rational expectations and economic policy (University of Chicago Press, Chicago, IL).

Shiller, Robert J. and Jeremy Seigel, 1977, The Gibson paradox and historical movements in real interest rates, Journal of Political Economy 85, 891-907.

Timberlake, Richard H., 1963, Mr. Shaw and his critics: Monetary policy in the golden era review, Quarterly Journal of Economics 77, no. 1, Feb., 41-54.

Timberlake, Richard H., 1978, The origins of central banking in the United States (Harvard University Press, Cambridge, MA).

Timberlake, Richard H., 1984, The central banking role of clearing house associations, Journal of Money, Credit and Banking 15, no. 1, Feb., 1-15.

Warburg, Paul M., 1930, The federal reserve system: Its origins and growth, vol. II (Macmillan, New York).

White, Eugene N., 1983, The regulation and reform of the American banking system, 1900-1929 (Princeton University Press, Princeton, NJ).

Willis, H. Parker, 1915, The Federal Reserve: A study of the banking system of the United States (Doubleday, Page and Co, New York).

Working. Holbrook, 1960, A note of the correlation of first differences of averages in a random chain, Econometrica 28, 916-918.

\title{
COMMENTS
}

\author{
'The Worldwide Change in the Behavior of Interest Rates and Prices in 1914' \\ by R.B. Barsky, N.G. Mankiw, J.A. Miron and D.N.Weil
}

\section{Giorgio BASEVI}

The question explored in this paper is whether the change of regime that has taken place internationally in terms of more stable interest rates after 1914, should be attributed to the breakdown of the gold standard or to the creation of the Federal Reserve System. The authors' thesis is that it was mainly due to the creation of the Fed, and not to the dismantling of the gold standard. The logical structure of their argument is remarkably complete, as I shall try to show in a schematic way, leaving aside many of its refinements. 